\title{
Investigation of the Effect of Regular Exercise on Some Motoric Features in Children in the 7-12 Age Group
}

\author{
Kürşat Hazar ${ }^{1}$ \\ ${ }^{1}$ Department of Physical Education and Sports Rectorate, Muğla, Turkey \\ Correspondence: Kürşat Hazar, Department of Physical Education and Sports Rectorate, Muğla, Turkey. E-mail: \\ kursathazar@hotmail.com
}

Received: February 17, 2019

Accepted: March 15, 2019 Online Published: March 29, 2019

doi:10.5539/jel.v8n3p81

URL: https://doi.org/10.5539/jel.v8n3p81

\begin{abstract}
The aim of this study was to investigate the effects of regular exercise on some motoric features in 7-12-year-old boys and girls in 8 weeks period of time. To the study 66 boys with an average age of $8, \pm 7963$, as 54 of them in research and 12 of them in control groups; 66 girls, 36 of them as research and 30 as control group, a total of 132 individuals who joins summer sports schools within the body of Muğla Sitkı Koçman Directorate of Health, Culture and Sports with no health problems participated in the study. Two tests were applied to the children before and after the exercise program. Height, body weight, balance, flexibility, bounce force, explosive force, sit-up and $20 \mathrm{~m}$ velocity measurements were performed to the participants. SPSS 21.00 package program was used for statistical evaluation of the obtained data. For paired comparisons, Paired Samples t test was applied to determine the effect of the independent variable on the dependent variable. In order to determine the difference between the groups, Independent samples t test was applied and the level of significance was set at $p<0.05$ and 0.01. In the study, statistically significant differences were found in favor of the research group between the first and second measurement results of height, body weight, balance, flexibility, bounce force, explosive force, sit-up and velocity $(\mathrm{p}<0.05, \mathrm{p}<0.01)$. As a result, in the light of the data obtained from the comparisons between the groups, it was determined that the regularly performed exercises positively affect the body weight, static balance, flexibility, bounce force, explosive force, sit-up and velocity values in 7-12 age group boys and girls.
\end{abstract}

Keywords: child, exercise, motoric features

\section{Introduction and Aim}

Although the human organism was created for movement, the advancement in technology and transportation opportunities resulted in the emergence of machines that saved manpower and reduced the ability to move.

Depending on the need to act on a steadily increasing basis, the importance of sports in the social sense is better perceived, which in turn leads to positive developments by attracting the attention of sports scientists. In particular, it is a frequently discussed issue that children in developmental age cause immobile life along with technological developments and a number of developmental problems (Alpay, Altuğ, \& Hazar, 2007).

Whereas sports and exercise in children; besides psychological, sociological development, as well as while providing gaining basic motoric features and a healthy body, it is known that the sports increases physical fitness levels, is an important factor in treatment of some diseases and protection from diseases, the sports positively affect cognitive functioning and self-esteem, depression and overall health status (Erkal, 1992).

While immobile life leads to excessive weight, it increases the risk of development of children and the prevalence of obesity, as well as increasing the risk of developing various chronic diseases in later life. In recent years, many national and international organizations have recommended that children participate in physical activities within an average of 60 minutes both inside and outside the school (Biddle et al., 2018).

The child needs to exercise in order to demonstrate the strength of his anatomic, physiological and psychological aspects and to demonstrate his strength in situations where he needs to maintain his vital activities. If these conditions are met, sports and exercise serve as preventive medicine and help the individual to be resistant to various diseases while improving his overall health. Sports which develops sports self-confidence, group awareness, sharing, social solidarity, also contribute to the socialization of the child and the development in the level of culture of the community (Bockous, Farrow, \& Friedl, 1990). 
The main purpose of exercise for health is to prevent the physical and organic disorders caused by inactive life, to increase the physiological capacity that constitutes the basis of body health, to maintain physical fitness and overall health for many years (Dündar, 1998).

In today's world, the importance of regular exercise in terms of general health protection is becoming more evident. The operation of the muscles, bones, joints, cardiovascular system and functions is ensured at the optimum level via exercises. Cardiovascular, blood pressure and diabetes diseases are less common in exercising people (Akgün, 1989).

Motor development in children is the ability of the organism to move depending on the growth and development of body organs such as muscle, bone, circulatory and nervous system. With the planned exercise programs; strength, flexibility, balance, speed, power, coordination and agility components can be developed (Kosar \& Demirel, 2004).

Physical growth and motor development proceed in proportion. While the growth of the body in the 7-11 age range is continuous but slow and regular, the parts of the body are quite functional. At this stage, the child is able to perform movements starting from simple reflex movements and becoming increasingly complex. At this age, motor control, balance and coordination develop. The development of motor productivity is accelerating at the ages of 8-11 and 11-13 in primary and secondary school years. In this period, there is an increase in movement speed. The speed capacity reaches its peak at the age of 10 years. Reaction speed develops later (Kerkez, Kalkavan, \& Öztürk, 2001).

Children in this development period show great interest in sports exercises, they generally Show tendency to learn and develop and tend to enjoy activities and learn alerts more quickly (Bockous, Farrow, \& Friedl, 1990).

Similar studies have been seen in the literature in accordance with this information. In this study, it is seen that it is important to determine the level of changes in the motor features of children who do not have any sports groundwork and attend summer sports schools and do regular exercises for 8 weeks and who do not. Therefore the aim of the study is to compare the changes in motor features that can occur in children between 7-12 years of age by determining the effect of regular exercise for 8 weeks.

\section{Material and Method}

\subsection{Participants}

The children participated in the study who enrolled summer sports schools in Muğla Sitkı Koçman University Directorate of Health, Culture and Sports and the children who received health report and permissions from their parents. The research group includes 90 individuals, who state that they do not have any sports groundwork, whose average height is $131.27 \mathrm{~cm}$, average weight is $32.35 \mathrm{~kg}$, age average is 8.74 years; the control group has 42 individuals whose age average şs 9.52 years, height average is $134.47 \mathrm{~cm}$, and weight average is $33.40 \mathrm{~kg}$; a total of 132 children voluntarily participated in the study. In the summer sports school, by giving children 2-hour aerobic exercises in the educational play format under the supervision of the trainer five days a week, their pre and post measurements were carried with 8-weeks break.

\subsection{Data Collection Methods}

Height and body weight, balance, flexibility, standing long jump, explosive force, sit-up and $20 \mathrm{~m}$. Velocity measurements of the research and control group were respectively made.

\subsection{Height and Weight Measurements}

The length of the research group is done with a stadiometer (SECA, Germany) with a precision of $0.01 \mathrm{~m}$, and body weight measurements were completed with an electronic scale (SECA, Germany) with a precision of 0.1 $\mathrm{kg}$.

\subsection{Balance Measurements}

The static balance of the research and control group was determined using the Flamingo Balance Test-FBT measurement tool. According to the test, researchers try to stand in balance with the dominant foot on an iron balance beam, which is $50 \mathrm{~cm}$ long, $4 \mathrm{~cm}$ height and $3 \mathrm{~cm}$ width. He pulls his other foot from his knee bent to the buttocks and holds it with his hand on the same side. The time is started when the one foot is in balance and tries to remain in balance for 1 minute. In cases where the balance is broken (when he leaves his feet, falls from the beam, touches the floor with any part of his body and so on) the time is stopped. The participant makes his balance again by going to the balance beam and the time continues where he left off. When the period is completed, the researcher's attempt to achieve balance is recorded as a number (Şipal, 1989). 


\subsection{Flexibility Measurements (Sit and Reach Test-SRT)}

Sit and reach test was used in determining the flexibility values of the research group. The top of a table was divided into cm's and designed, height and length of which is 32 , and 35, respectively. The participants sat on the floor, extend their legs and hold the soles of their shoeless feet to the table. Then as far as possible, extends on the table forward from the body (waist and hips) to forward, without bending the knees. The farthest point where the fingers reach is measured in terms of $\mathrm{cm}$. The measurements were recorded at best after 3 repeats.

\subsection{Standing Long Jump Measurement}

The tape measure was used to determine the distance in the standing long jump test. The participants were held backward by taking their arms back in half squat position and the two legs parallel to each other, waiting behind the starting line, then moving their arms forward upwards to leap forward. The participant falls to the ground. While his feet are parallel, the body is twisted and the arms in forward. In the standing long jump test, the distance between the starting line and the place where the participant's closest contact to the line was measured in $\mathrm{cm}$. The test was performed twice and the better value was recorded. The reliability of this test was reported to be 0.70-0.94 (Özkara, 2002).

\subsection{Explosive Force Measurements}

The explosive strength of the upper extremity was obtained by using $400 \mathrm{~g}$ of VES400 mercury silicon child shot put. For the participants, a starting line was determined and they were asked to throw the shot put to the farthest point where they could throw the line. The point where the shot put was thrown was recorded in $\mathrm{cm}$.

\subsection{Sit-Up Measurements}

After pre-warmup of the research group, they were asked to lie on supine position, the knees were twisted to the abdominal region and his feet were held by the helper as the feet sole would touch the ground. The participant was asked to go to the sitting position and to lie again on his back while his hands were crossed in the chest and his back was over 90 degrees. Using the stopwatch method, he was asked to perform the sit-up as may as he could for 30 seconds (Mengütay, 2005).

\subsection{Velocity Measurements}

An electronic Prosport TMR ESC 2100 telemetric stopwatch is used to determine the velocity of 20 meters. The velocity measurement was measured by determining a distance of 20 meters in the gym. The participants started the test at any time from the starting line, one meter behind the starting photocell. The measurements were made with photocells placed at the start and end of the 20-meter running distance. Two measurements were taken twice at 3-minute rest intervals and the better grade was evaluated. The reliability coefficient of this test is reported to be 0.74-0.97 (Özkara, 2002).

\subsection{The Analysis of the Data}

The statistical evaluation of the obtained data was done in SPSS 21.00 package program on a personal computer. For paired comparisons, Paired-Samples t-test was applied to determine the effect of the independent variable on the dependent variable. The t-test was used for independent groups. The level of significance was designed as ( $p$ $<0.05,0.01)$.

\section{Findings}

A total of 132 children with a mean age of $8, \pm 7963$ were surveyed, a total of 66 male individuals, 12 of them were in control group, a total of 66 female individuals, 30 of them were in control group; measurement results of 132 children's pre-test and post-test are presented. 
Table 1. Comparison of pre-test post-test measurement results of the groups in terms of height and body weight values

\begin{tabular}{|c|c|c|c|c|c|c|}
\hline & Groups & Variables & $\overline{\mathbf{x}}$ & df & $\mathrm{t}$ & $\mathrm{p}$ \\
\hline \multirow[t]{4}{*}{ Male Height $(\mathrm{cm})$} & Research & Pre-Test & 131.351 & 10.262 & & \\
\hline & Group & Post-Test & 132.257 & 10.311 & -20.661 & $000 * *$ \\
\hline & Control & Pre-Test & 132.666 & 12.543 & & \\
\hline & Group & Post-Test & 133.75 & 12.819 & -10.457 & $.000 * *$ \\
\hline \multirow[t]{4}{*}{ Female Height $(\mathrm{cm})$} & Research & Pre-Test & 131.166 & 9.308 & & \\
\hline & Group & Post-Test & 132.010 & 9.330 & -19.709 & $.000 * *$ \\
\hline & Control & Pre-Test & 135.200 & 8.922 & & \\
\hline & Group & Post-Test & 136.216 & 8.980 & -13.098 & $.000 * *$ \\
\hline \multirow[t]{4}{*}{ Male Weight (kg) } & Research & Pre-Test & 33.370 & 4.401 & & \\
\hline & Group & Post-Test & 32.074 & 4.259 & 9.009 & $.000 * *$ \\
\hline & Control & Pre-Test & 37.041 & 4.535 & & \\
\hline & Group & Post-Test & 38.150 & 4.554 & -6.408 & $.000 * *$ \\
\hline \multirow[t]{4}{*}{ Female Weight (kg) } & Research & Pre-Test & 30.833 & 4.246 & & . \\
\hline & Group & Post-Test & 29.583 & 4.122 & 8.919 & $000 * *$ \\
\hline & Control & Pre-Test & 31.950 & 6.749 & -7.002 & $.000 * *$ \\
\hline & Group & Post-Test & 33.526 & 7.182 & & \\
\hline
\end{tabular}

Table 1 shows that there is a significant difference between the first and second measurement values of the height and body weight average of boys and girls in the research group $(\mathrm{p}<0.01)$. It is seen that while the mean height values of the children in the research and control group increased, the average body weight value of the study group decreased and the body weight value of the control group increased $(p<0.01)$.

Table 2. Comparison of Pre-Test and Post-Test Measurement Results of the Groups in terms of Balance and Flexibility Values

\begin{tabular}{|c|c|c|c|c|c|c|}
\hline & Groups & Variables & $\overline{\mathbf{x}}$ & df & $\mathrm{t}$ & $\mathrm{p}$ \\
\hline \multirow[t]{4}{*}{ Male Balance (min. pcs) } & Research & Pre-Test & 11.8889 & 1.50052 & & \\
\hline & Group & Post-Test & 10.7778 & 1.81884 & 4.832 & $.000 * *$ \\
\hline & Control & Pre-Test & 12.0185 & 1.80660 & & .852 \\
\hline & Group & Post-Test & 12.0556 & 1.50993 & -.187 & \\
\hline \multirow[t]{4}{*}{ Female Balance (min. pcs) } & Research & Pre-Test & 12.1389 & 1.41730 & & \\
\hline & Group & Post-Test & 10.6667 & 1.47358 & 5.957 & $.000 * *$ \\
\hline & Control & Pre-Test & 11.8056 & 1.61810 & -.502 & .619 \\
\hline & Group & Post-Test & 11.9444 & 1.89653 & & \\
\hline \multirow[t]{4}{*}{ Male Flexibility (cm) } & Research & Pre-Test & 29.333 & 4.797 & -8.206 & $.000 * *$ \\
\hline & Group & Post-Test & 32.444 & 5.462 & & \\
\hline & Control & Pre-Test & 26.916 & 5.615 & -2.489 & $.030 *$ \\
\hline & Group & Post-Test & 27.491 & 5.715 & & \\
\hline \multirow[t]{4}{*}{ Female Flexibility $(\mathrm{cm})$} & Research & Pre-Test & 33.111 & 12.086 & -4.002 & $.000 * *$ \\
\hline & Group & Post-Test & 38.123 & 9.278 & & \\
\hline & Control & Pre-Test & 23.500 & 7.238 & -3.463 & $.002 *$ \\
\hline & Group & Post-Test & 25.030 & 8.074 & & \\
\hline
\end{tabular}

Note. $* \mathrm{p}<0.05, * *: \mathrm{p}<0.01$.

Table 2 shows that there is a significant difference in the balance values between the pre-test and post-test values in favor of the research group $(\mathrm{p}<0.01)$. In terms of flexibility values, it was determined that there was a significant difference between the pre-test and post-test values in favor of both groups $(p<0.01, p<0.05)$. 
Table 3. Comparison of the measurement results of the groups' bounce force and explosive force values

\begin{tabular}{|c|c|c|c|c|c|c|}
\hline & Groups & Variables & $\overline{\mathbf{x}}$ & df & $\mathrm{t}$ & $\mathrm{p}$ \\
\hline \multirow[t]{4}{*}{ Male Bounce Force (m) } & Research & Pre-Test & 1.068 & .282 & & \\
\hline & Group & Post-Test & 1.209 & .325 & -4.821 & $.000 * *$ \\
\hline & Control & Pre-Test & 1.503 & .307 & & \\
\hline & Group & Post-Test & 1.339 & .269 & 1.909 & .083 \\
\hline \multirow[t]{4}{*}{ Female Bounce Force (m) } & Research & Pre-Test & 1.069 & .281 & & \\
\hline & Group & Post-Test & 1.270 & .350 & -4.476 & $.000 * *$ \\
\hline & Control & Pre-Test & 1.399 & .356 & & \\
\hline & Group & Post-Test & 1.416 & .275 & -.547 & .588 \\
\hline \multirow[t]{4}{*}{ Male Explosive Force (m) } & Research & Pre-Test & 2.926 & 1.387 & & \\
\hline & Group & Post-Test & 3.335 & 1.506 & -7.379 & $.000 * *$ \\
\hline & Control & Pre-Test & 4.332 & .389 & & \\
\hline & Group & Post-Test & 4.530 & .600 & -2.412 & $.035^{*}$ \\
\hline \multirow[t]{4}{*}{ Fmale Explosive Force (m) } & Research & Pre-Test & 3.031 & 1.402 & & \\
\hline & Group & Post-Test & 3.423 & 1.576 & -6.369 & $.000 * *$ \\
\hline & Control & Pre-Test & 3.459 & .803 & & \\
\hline & Group & Post-Test & 3.900 & .825 & -7.942 & $.000 * *$ \\
\hline
\end{tabular}

Note. ${ }^{*} \mathrm{p}<0.05,{ }^{* *}: \mathrm{p}<0.01$.

As shown in Table 3, there was a significant difference between pre-test and post-test results of male and female individuals' bounce force $(\mathrm{p}<0.01)$, but there was no significant difference between pre-test and post-test results of the control group was found ( $p>0.05)$. Nonetheless, there was a significant difference between children's explosive force pre-test and post-test results in favor of all groups $(\mathrm{p}<0.01, \mathrm{p}<0.05)$.

Table 4. Comparison of the groups' sit-up and velocity measurement values

\begin{tabular}{|c|c|c|c|c|c|c|}
\hline & Groups & Variables & $\overline{\mathbf{x}}$ & $\mathrm{df}$ & $\mathrm{t}$ & $\mathrm{p}$ \\
\hline \multirow[t]{4}{*}{ Male Sit-up (30sn) } & Research & Pre-Test & 17.833 & 5.715 & & \\
\hline & Group & Post-Test & 20.463 & 5.347 & -12.126 & $.000 * *$ \\
\hline & Control & Pre-Test & 21.083 & 1.880 & & \\
\hline & Group & Post-Test & 21.000 & 2.593 & .115 & .910 \\
\hline \multirow[t]{4}{*}{ Female Sit-up (30sn) } & Research & Pre-Test & 18.750 & 4.964 & & $.000 * *$ \\
\hline & Group & Post-Test & 21.083 & 4.619 & -8.201 & \\
\hline & Control & Pre-Test & 17.933 & 4.184 & & \\
\hline & Group & Post-Test & 17.866 & 3.739 & .177 & .861 \\
\hline \multirow[t]{4}{*}{ Male Velocity (20m/sn) } & Research & Pre-Test & 5.442 & 1.431 & & \\
\hline & Group & Post-Test & 5.260 & 1.419 & 7.626 & $.000 * *$ \\
\hline & Control & Pre-Test & 4.022 & .578 & & \\
\hline & Group & Post-Test & 4.028 & .784 & -.545 & .964 \\
\hline \multirow[t]{4}{*}{ Female Velocity $(20 \mathrm{~m} / \mathrm{sn})$} & Research & Pre-Test & 5.400 & 1.143 & & \\
\hline & Group & Post-Test & 5.114 & 1.180 & 7.304 & $.000 * *$ \\
\hline & Control & Pre-Test & 4.079 & .437 & & \\
\hline & Group & Post-Test & 5.980 & 9.279 & -1.134 & .266 \\
\hline
\end{tabular}

Note. ${ }^{*} \mathrm{p}<0.05,{ }^{* *}: \mathrm{p}<0.01$.

In Table 4, there was a significant difference between the pre-test and post-test measurement values of sit-up and velocity of the boys and girls in the research group $(p<0.01)$, while there was no significant difference between the measurement results of the control group $(\mathrm{p}>0.05)$.

\section{Discussion and Result}

In this study, carried out with 132 children in 7-12 age group, 42 of them in control groups and 90 of them in research group, 8-weeks regular exercises' effect on motoric features of the children were researched.

A significant difference was found between the pre-test and post-test measurements of the height and weight of boys and girls in the study $(\mathrm{p}<0.01)$. It was stated that while the average height of the children in the research and control group increased, the average weight of the research group and the control group increased.

Watts et al. (2003) reported that there were significant differences in height and weight averages of age-matched children with regular exercise training and those who not. While Backous et al. (1990) reported that they found 
significant differences in terms of weight among male adolescents who did regular exercise and those who did not, Saygin et al. (2005) reported that long-term regular movement training programs positively affect the physical fitness features of 10-12-year-old children. There are many studies reporting the positive effect of exercise on body mass index (Mitchell et al., 2018; Guo et al., 2018). While it is assumed that doing regular exercises have an effect on the children's losing weight in the research group, it is seen that the study coincides with the literature.

It was found that there was a significant difference $(p<0.01)$ between the pre-test and post-test measured values of the boys in the study group. Although there was an increase in the balance values of the children in the research group, there was no significant difference between the balance values of the children in the control group ( $p>0.05$ ). Ün et al. (2001), in their study to investigate the effect of sports on sports and non-sports children, found that the development of balance and strength in the class of gross motor skills were found to be significantly higher in sports doers. In their study of Wallchle et al. (2018), they suggested that balance training for children and postural control could be trained earlier than 6 years of age. In our study, it was assumed that doing regular exercise was effective for male children's high balance values in the research group.

A significant difference was found in flexibility parameter between pre-test and post-test measured values of the boys and girls in the research and control group in favor of both groups $(\mathrm{p}<0.05, \mathrm{p}<0.01)$. In a study they conducted, Kerkez et al. (2001) found that the flexibility values were 13.73 in 11 years old boys. In a study in which Yenal et al. (1999) investigated the effect of physical education and sports activities on motor skills and abilities in children aged 10-11 years who are in primary school second terms, they found flexibility significantly in favor of research group in proportion to control group. In a similar study, Saygin (2003) found a significant difference in flexibility between children with mild and moderate activity levels. In their study, Ludgy et al. (2018) reported that aerobic exercise was beneficial for children in terms of flexibility. These research findings support our findings.

While there was a significant difference between the pre-test and post-test results of the bounce force of boys and girls in the research group $(\mathrm{p}<0.01)$, it was found that there was no significant difference between the pre-test and post-test results of the control group $(\mathrm{p}>0.05)$. However, it was found that there was a significant difference in favor of all groups between the results of explosive force pre-test and post-test measurements of the children ( $\mathrm{p}<0.01, \mathrm{p}<0.05$ ). In a study conducted by Kosar and Demirel (2004), muscle strength, muscle mass, endurance, nerve and reaction time development, muscle metabolic level and body size increase in children in growth and development period. In this direction, anaerobic capacity and the speed increase is observed. In the same study, they state that muscle strength increases with age in both boys and girls, and the main reason for this is increased muscle mass due to height and body weight. In this study, while it is thought that the reason why there is more increase in bounce force of the male and female children of the research group in proportion to control group is doing regular exercise, the reason for the increase in the explosive force properties in all groups is the reason for the changes in the body during growth and development period.

While it was found that there was a significant difference between the test and pre-test and post-test measurements of the boys and girls in the research group in terms of sit-up and velocity, there was no significant difference between the measurement results of the control group ( $p>0.05)$. Şipal (1989) reported that warming, training time, stretching, avoiding unnecessary releases of the body during exercise, intensive exercises, exercise techniques, and tactics, step length, and frequency, conducted speed studies, the speed of isometric and isotonic studies affect speed feature. In this sense, it is seen that boys and girls in the research group use the abdominal and leg muscles more effectively depending on regular exercises.

In a study conducted by Han et al. (2018), it was found that overweight and obese children had basic mobility at lower levels than healthy weight peers, however, while physical activity interventions were reported to be effective in improving their skills, motor coordination activities are recommended in order to upgrade the ability development to the top level.

As a result, besides the obtained data from the comparisons between the groups state that regular exercises positively affect the body weight, static balance, flexibility, bounce force, explosive force, sit-up and velocity values in 7-12 age boys and girls, such exercise programmes are considered to contribute to the children's motoric development. In addition, this research is considered to be a source for other researches related to the development and development of motor development of the 7-12-year-old boys and girls.

\section{References}

Akgün, N. (1989). Egzersiz fizyolojisi (3. bask1, 1. cilt). Ankara. 
Alpay, B., Altuğ, K., \& Hazar, S. (2007). Illköğretim Okul Takımlarında Yer Alan 11-13 Yaş Gurubu Ögrrencilerin Bazı Solunum ve Dolaşım Parametrelerinin Spor Yapmayan Öğrencilerle Karşılaştırılarak Değerlendirilmesi.

Biddle, S. J., Ciaccioni, S., Thomas, G., \& Vergeer, I. (2018). Physical activity and mental health in children and adolescents: An updated review of reviews and an analysis of causality. Psychology of Sport and Exercise. https://doi.org/10.1016/j.psychsport.2018.08.011

Biddle, S. J., Sallis, J. F., \& Cavill, N. (1998). Young and active? Young people and health-enhancing physical activity-evidence and implications. Health Education Authority.

Bockous, D. D., Farrow J. A., \& Friedl, K. E. (1990). Assesment of Maturity in Boys and Grip Strength. $J$ Adolesc Healty Care, 11(6), 497-500. https://doi.org/10.1016/0197-0070(90)90109-F

Dündar, U. (1998). Antrenman Teorisi (4.baskı). Ankara: Bağırgan.

Erkal, N. (1992). Sosyolojik Açıdan Spor. İstanbul: Kutsun Matbaa ve Reklamcılık Merkezi.

Faigenbaum, A. D., Rebullido, T. R., \& MacDonald, J. P. (2018). Pediatric inactivity triad: a risky PIT. Current Sports Medicine Reports, 17(2), 45-47. https://doi.org/10.1249/JSR.0000000000000450

González-Ruíz, K., Correa-Bautista, J. E., Izquierdo, M., García-Hermoso, A., Dominguez-Sanchez, M. A., Bustos-Cruz, R. H., ... \& Prieto-Benavides, D. H. (2018). Effects of an Exercise Program on Hepatic Metabolism, Hepatic Fat and Cardiovascular Health in Overweight/Obese Adolescents From Bogota, Colombia (The HEPAFIT Study): Study Protocol for A Randomized Controlled Trial. Trials, 19(1), 330. https://doi.org/10.1186/s13063-018-2721-5

Guo, H., Schenkelberg, M. A., O’Neill, J. R., Dowda, M., \& Pate, R. R. (2018). How Does the Relationship Between Motor Skill Performance and Body Mass Index Impact Physical Activity in Preschool Children? Pediatric Exercise Science, 30(2), 266-272. https://doi.org/10.1123/pes.2017-0074

Han, A., Fu, A., Cobley, S., \& Sanders, R. H. (2018). Effectiveness of Exercise İntervention on Improving Fundamental Movement Skills and Motor Coordination in Overweight/Obese Children and Adolescents: A Systematic Review. Journal of Science and Medicine in Sport, 21(1), 89-102. https://doi.org/10.1016/j.jsams.2017.07.001

Hazar, S., \& Ateşoğlu, Ü. (2004). Farklı Türdeki Kuvvet Egzersizlerinin Bağış̧ılık Sistemine Akut Etkisi/Acute Effect of Various Strength Exercise Methods on Immune System. Beden Eğitimi ve Spor Bilimleri Dergisi, $6(4), 45-53$.

Kerkez, F., Kalkavan, A., \& Öztürk, A. (2001). Bazı psikomotor ve fiziksel özelliklerin koordinatif yeteneğe etkisinin 9-11 yaş grubu erkek çocukların üzerinde araştırılması. Spor araştırmaları der (Cilt:5, sayı:1, s: 19-27). İstanbul.

Koşar, N. Ş., \& Demirel, H. A. (2004). Çocuk sporcuların fizyolojik özellikleri. Acta orthopaedica et traumatologicaturcica suplementum, 1(38), 1-15.

Ludyga, S., Gerber, M., Mücke, M., Brand, S., Weber, P., Brotzmann, M., \& Pühse, U. (2018). The acute effects of aerobic exercise on cognitive flexibility and task-related heart rate variability in children with ADHD and healthy controls. Journal of Attention Disorders, 1087054718757647. https://doi.org/10.1177/1087054718757647

Mengütay, S. (2005). Çocuklarda hareket eğitimi ve spor. İstanbul. Morpa.

Mitchell, E. A., Stewart, A. W., Braithwaite, I., Murphy, R., Hancox, R. J., Wall, C., \& ISAAC Phase Three Study Group. (2018). Factors associated with body mass index in children and adolescents: An international cross-sectional study. PloS one, 13(5), e0196221. https://doi.org/10.1371/journal.pone.0196221

Özkara, A. (2002). futbolda testler. Ankara: ilksan matbaacıllk. physical activity: evidence and implications. london, health educationauthority.

Saygın, Ö., Polat, Y., \& Karacabey, K. (2005). Çocuklarda Hareket Eğitiminin Fiziksel Uygunluk Özelliklerine Etkisi. Firat Üniversitesi Sağllk Bilimleri Tip Dergisi (Cilt 19, Sayı 3, Sayfa 205-212).

Saygın, Ö. (2003). 10-12 Yaş Çocukların Fiziksel Aktivite Düzeyleri Ve Fiziksel Uygunluklarının Incelenmesi. M.Ü. Sağ. Bil. Ens. Bed. Eğt. ve Spor Abd. Yayınlanmamış Doktora Tezi. İstanbul. 
Sharara, E., Akik, C., Ghattas, H., \& Obermeyer, C. M. (2018). Physical inactivity, gender and culture in Arab countries: a systematic assessment of the literature. BMC Public Health, 18(1), 639. https://doi.org/10.1186/s12889-018-5472-z

Şipal, M. C. (1989). Eurofit Bedensel Yetenek Testleri El Kitabı. T.C. Başbakanlık G.S.G.M Dıı̧ İlişkiler Dairesi Başkanlığı Yayını, Yayın No 78. Ankara.

Ün, N., Erbahçeci, F., \& Ergun, N. (2001). mental retarde çocuklarda fiziksel uygunluğun değerlendirilmesi. Romatizma, 16(1), 16-21.

Wälchli, M., Ruffieux, J., Mouthon, A., Keller, M., \& Taube, W. (2018). Is young age a limiting factor when training balance? Effects of child-oriented balance training in children and adolescents. Pediatric Exercise Science, 30(1), 176-184. https://doi.org/10.1123/pes.2017-0061

Watts, P. B., Joubert, L. M., Lish, A. K., Mats, J. D., \& Wilkins, B. (2003). Anthropometry of Young Competitive Sport Rock Climbers. Br J Sport Med, 37(5), 420-424. https://doi.org/10.1136/bjsm.37.5.420

Yenal, T. H., Çamlıyer, H., \& Saraçoğlu, A. S. (1999). İlköğretim İkinci Devre Çocuklarında Beden Eğitimi ve Spor Etkinliklerinin Motor Beceri ve Yetenekler Üzerine Etkisi. G.Ü. Besbd, 4(3), 15-24, Ankara.

\section{Copyrights}

Copyright for this article is retained by the author, with first publication rights granted to the journal.

This is an open-access article distributed under the terms and conditions of the Creative Commons Attribution license (http://creativecommons.org/licenses/by/4.0/). 